\title{
Elimination of microbes from different drinking water sources of Visakhapatnam using potassium permanganate: dose based disinfection approach
}

\author{
Anima S. Dadhich ${ }^{1, a}$, H. Rahaman Khan ${ }^{2, b}$ \\ ${ }^{1}$ Department of Chemistry, GITAM Institute of Science, GITAM University, Visakhapatnam, \\ Andhra Pradesh, India \\ 2Department of Biotechnology, GITAM Institute of Science, GITAM University, Visakhapatnam, \\ Andhra Pradesh, India \\ a,bE-mail address: animasunil@hotmail.com , h.rahamankhan@gmail.com
}

\begin{abstract}
Potassium permaganate has been used since ages for disinfection of water. It is known for oxidation of cell membrane of micro organisms. But the pink colour prevailing after use makes people reject the water on aesthetic grounds. Water samples from bore wells and tap water from public places were collected from different areas of Visakhapatnam. Physio-chemical and microbial analysis analyses of the water samples were carried out. A dose based permaganate treatment of water depending upon number of colony forming units and species of microorganism present in the water was carried out $[1,2,5]$.
\end{abstract}

Keywords: Potassium permanganate; Bergy's Manual; AWWA; B.I.S.

\section{INTRODUCTION}

Water sanitation is crucial for health therefore it is necessary to evaluate the microbial quality of drinking water. Chlorination, which is generally employed for disinfection of water leads to the formation of THM's (Tri Halo Methane) compound which include chloroform, bromoform etc. People generally use cloth filtration which removes particulate matter but does little to eradicate microbes from water.

In some places alum is used which only coagulates the suspended matter resulting in less number of bacterial colonies but complete eradication of microbial population is not achieved by any of these processes. Potassium permagnate has been used since ages for disinfection of water.

It is known for its oxidation of cell membrane of micro organisms. But the pink colour prevailing after use makes people reject the water on aesthetic grounds. Previous research show that high dose of permagnate are required for complete disinfection of water.

A dose of $20 \mathrm{mg} / \mathrm{L}$ and contact times of 24 hours were necessary to deactivate many pathogens and at that concentration the water turned an objectionable pink color.

Hazen and Sawyer (1992) [5] reported that complete removal of coliform bacteria was accomplished at doses of $1,2,3,4,5$, and $6 \mathrm{mg} / \mathrm{L}$. 
Present study was conducted in different parts of Visakhapatnam city, a Northern District of Andhra Pradesh. Water samples from different bore wells in residential areas and tap water from public places were collected. Physio-chemical and microbial analysis analyses of the water samples were carried out.

The areas included in our study are inhabited by heterogeneous strata of society which lack basic awareness about water sanitation. We have made an attempt to carry out a dose based permagnate treatment of water depending upon number of colony forming units and species of microorganism present in the water.

Yet restricting the amount of Mn within the permissible limit for drinking water as prescribed by B.I.S (extended upto $0.5 \mathrm{mg} / \mathrm{l}$ ).

\section{MATERIALS \& METHODS}

Analytical grade chemicals were purchased from Merck, Himedia Laboratories Pvt. Ltd., SRL Chemical Pvt. Ltd., Qualigens Chemicals.

\section{1. Biochemical Characterization}

Isolation of bacteria and their characterization was performed as per standard procedures (Bergy's Manual for Classification of Bacteria) [7-13].

\section{2. Chemical Parameters}

The water samples were analyzed for Dissolved Oxygen, Residual Chlorine, Nitrite, Ammonia, Sulphides \& Sulphates all the test were performed as per standard protocol described by APHA [16].

\section{3. Methodology}

Bore well and tap water samples were collected in sterile PET bottles from different residential areas interspersed with slums and storage tanks in public places, respectively.

The bottles were rinsed with the sample water before collection and were then tightly sealed with a parafilm to prevent secondary contamination and were safely transported to the University's Lab for microbial characterization and other selected physicochemical parameters.

The water is then transferred to sterilized one liter glass bottles and then to each bottle Potassium Permanganate was added the dose was varied at $0.5 \mathrm{mg} / 1,1 \mathrm{mg} / \mathrm{L}$ and $2 \mathrm{mg} / \mathrm{L}$ concentration.

The bacterial count of the water samples was carried out after a period of $24 \mathrm{hrs}-72 \mathrm{hrs}$. The samples were screened for microbial growth up to $72 \mathrm{hrs}$. The isolates were then subjected to biochemical characterization like catalase, indole, methyl red, voges proskauer, citrate and motility test . 


\section{RESULTS}

Table 1. Bacterial Density and the number of selected isolates from drinking water samples.

\begin{tabular}{|c|c|c|c|c|c|c|c|c|c|c|c|}
\hline \multirow[t]{2}{*}{ Sample } & \multirow{2}{*}{$\begin{array}{c}\text { Cfu/ } 50 \mu \mathrm{l} \\
\text { before } \\
\text { treatment } \\
\text { with } \\
\mathrm{KMnO}_{4}\end{array}$} & \multirow{2}{*}{$\begin{array}{c}\text { Selected } \\
\text { isolates }\end{array}$} & \multicolumn{3}{|c|}{$\begin{array}{c}\text { Cfu/ } 50 \mu \mathrm{l} \text { after } \\
\text { treatment with } \\
\mathrm{KMnO}_{4} \\
\text { Dose: }(0.5 \mathrm{mg} / \mathrm{l})\end{array}$} & \multicolumn{3}{|c|}{$\begin{array}{c}\text { Cfu/ } 50 \mu \mathrm{l} \text { after } \\
\text { treatment with } \\
\mathrm{KMnO}_{4} \\
\text { Dose: }(1 \mathrm{mg} / \mathrm{l}) \\
\end{array}$} & \multicolumn{3}{|c|}{$\begin{array}{c}\mathrm{Cfu} / 50 \mu \mathrm{l} \text { after } \\
\text { treatment with } \\
\mathrm{KMnO}_{4} \\
\text { Dose: }(2 \mathrm{mg} / \mathrm{l}) \\
\end{array}$} \\
\hline & & & $\begin{array}{c}12 \\
\text { Hrs }\end{array}$ & $\begin{array}{c}36 \\
\text { Hrs }\end{array}$ & $\begin{array}{c}72 \\
\text { Hrs }\end{array}$ & $\begin{array}{c}12 \\
\text { Hrs }\end{array}$ & $\begin{array}{c}36 \\
\text { Hrs }\end{array}$ & $\begin{array}{c}72 \\
\text { Hrs }\end{array}$ & $\begin{array}{c}12 \\
\text { Hrs }\end{array}$ & $\begin{array}{c}36 \\
\text { Hrs }\end{array}$ & $\begin{array}{c}72 \\
\text { Hrs }\end{array}$ \\
\hline GW1 & 80 & 2 & 80 & 80 & 80 & 60 & 60 & 40 & - & - & - \\
\hline TP1 & 200 & 4 & 200 & 200 & 190 & 160 & 160 & 120 & 30 & - & - \\
\hline GW2 & 70 & 2 & 60 & 60 & 60 & 50 & 50 & 40 & - & - & - \\
\hline TP2 & 46 & 2 & 40 & 40 & 40 & 30 & 26 & 10 & - & - & - \\
\hline TP3 & 68 & 3 & 50 & 50 & 50 & 40 & 30 & 20 & - & - & - \\
\hline GW3 & 100 & 4 & 100 & 100 & 100 & 80 & 68 & 54 & - & - & - \\
\hline TP4 & 96 & 2 & 90 & 96 & 96 & 78 & 60 & 40 & - & - & - \\
\hline
\end{tabular}

* GW - Ground Water, TP - Tap Water

Analyzing a total of seven samples collected from different water sources of Visakhapatnam city yielded 19 isolates were selected for further characterization. The samples with high cfu were subjected to serial dilution (Ten fold) and then they were again subjected to biochemical characterization which allows the accurate identification of the bacterial fauna. The cfu was found out to be maximum in case of TP1 even at the $\mathrm{KMnO}_{4}$ dosage of $0.5 \mathrm{mg} / \mathrm{l}$ and the minimal growth was observed with the dosage of $2 \mathrm{mg} / \mathrm{l}$ with the contact period of $72 \mathrm{hrs}$. 
Table 2. Gram Staining.

\begin{tabular}{|c|c|}
\hline Sample & Gram Staining \\
\hline GW1 & Gram Positive Cocci \\
\hline TP1 & Gram Negative Cocci \\
\hline GW2 & Gram Positive Cocci \\
\hline GW2 & Gram Negative Cocci \\
\hline $\begin{array}{c}\text { TP2 } \\
\text { (Dilution 10-4) }\end{array}$ & Gram Positive Bacilli \\
\hline TP-3 & Gram Negative Bacilli \\
\hline $\begin{array}{c}\text { TP-3 } \\
\text { (Dilution 10-4) }\end{array}$ & Gram Negative Bacilli \\
\hline $\begin{array}{c}\text { GW-3 } \\
\text { (Dilution 10-4) }\end{array}$ & Gram Negative Bacilli \\
\hline $\begin{array}{c}\text { TP-4 } \\
\text { TP-4 } \\
\text { (Dilution 10-3) }\end{array}$ & Gram Negative Cocci \\
\hline $\begin{array}{c}\text { TP-4 } \\
\text { (Dilution 10-4) }\end{array}$ & Gram Positive Bacilli \\
\hline $\begin{array}{c}\text { TP-4 } \\
\text { (Dilution 10-5) }\end{array}$ & Gram Negative Cocci \\
\hline * GW - Ground Water, TP - Tap Water
\end{tabular}

After screening the isolates from different water sources the samples were subjected to Gram staining to establish the shape and the type of microbial species which could possibly be present in the water samples $[7,8]$.

Table 3. Morphological and biochemical observations of the different isolates from different water sources.

\begin{tabular}{|c|c|c|c|c|c|c|c|c|c|c|c|c|}
\hline 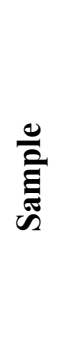 & E & 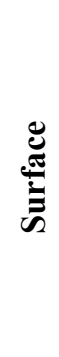 & $\frac{\grave{\partial}}{\dot{e}}$ & 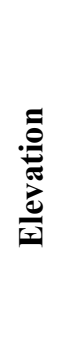 & 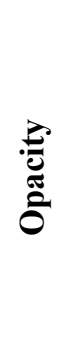 & 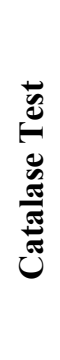 & $\begin{array}{l}\vec{v} \\
\stackrel{0}{0} \\
\frac{0}{0} \\
\frac{0}{g}\end{array}$ & 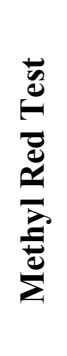 & 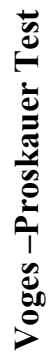 & 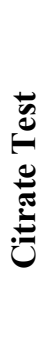 & & 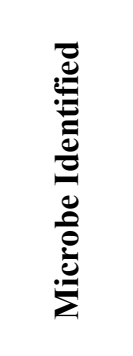 \\
\hline 勇 & 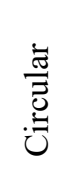 & 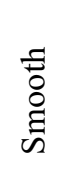 & 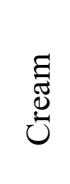 & 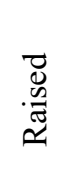 & $\begin{array}{l}\frac{o}{\tilde{\sigma}} \\
\text { ŏ }\end{array}$ & - & - & - & + & + & - & 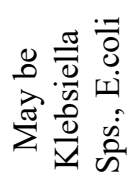 \\
\hline
\end{tabular}




\begin{tabular}{|c|c|c|c|c|c|c|c|c|c|c|c|c|}
\hline$\vec{\Xi}$ & 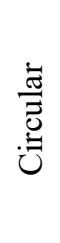 & $\begin{array}{l}\text { Fే } \\
8 \\
\text { : } \\
\text { w }\end{array}$ & $\frac{z}{\overline{0}}$ & $\stackrel{\overbrace{}}{0}_{0}^{x}$ & $\begin{array}{l}\frac{\tilde{J}}{\vec{E}} \\
\text { ô. }\end{array}$ & + & + & + & - & + & + & 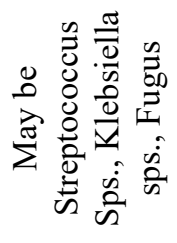 \\
\hline$\overbrace{0}^{N}$ & 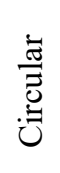 & 离 & 总 & 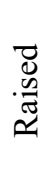 & $\begin{array}{l}\frac{\mathscr{U}}{\tilde{J}} \\
\text { م. }\end{array}$ & - & - & - & + & + & - & 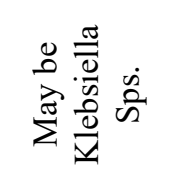 \\
\hline$\sum_{0}^{N}$ & 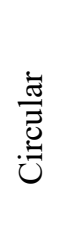 & $\begin{array}{l}\tilde{F} \\
0 \\
\vdots \\
\tilde{E}\end{array}$ & $\frac{0}{0}$ & 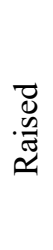 & $\begin{array}{l}\frac{\mathscr{g}}{\tilde{J}} \\
\stackrel{\tilde{\sigma}}{0}\end{array}$ & - & - & + & + & + & - & 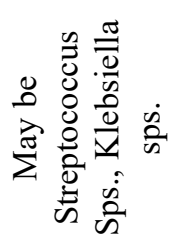 \\
\hline 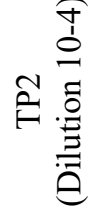 & 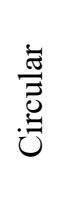 & $\begin{array}{l}\tilde{F} \\
0 \\
\vdots \\
\tilde{E}\end{array}$ & $\frac{3}{\overline{0}}$ & 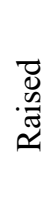 & 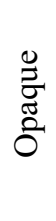 & - & - & - & - & + & - & 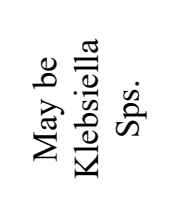 \\
\hline$\hat{\stackrel{\hat{n}}{H}}$ & $\begin{array}{l}\bar{\Xi} \\
\bar{J} \\
\bar{J}\end{array}$ & $\begin{array}{l}\text { F } \\
8 \\
\text { : } \\
\text { की }\end{array}$ & 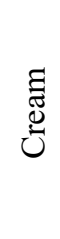 & 泀 & 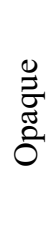 & - & + & + & - & + & + & 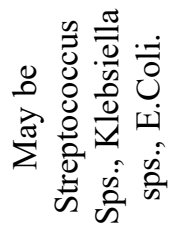 \\
\hline 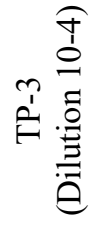 & 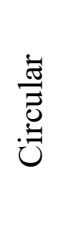 & 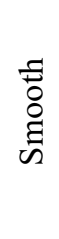 & 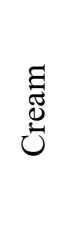 & 苞 & $\begin{array}{l}\frac{\mathscr{J}}{\tilde{J}} \\
\text { ö }\end{array}$ & - & + & + & - & - & + & 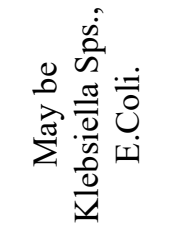 \\
\hline 章 & 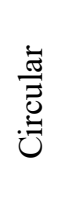 & 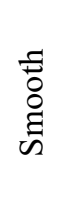 & $\frac{z}{\overline{0}}$ & 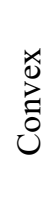 & 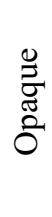 & - & + & + & - & - & - & 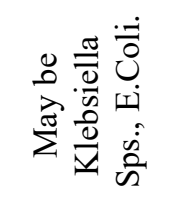 \\
\hline $\begin{array}{l}P_{F}^{\prime} \\
\stackrel{1}{\prime}\end{array}$ & 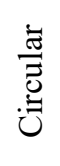 & 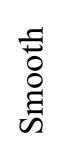 & $\stackrel{\substack{0\\
}}{\frac{0}{0}}$ & $\sum_{0}^{x}$ & 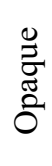 & - & + & - & - & - & - & 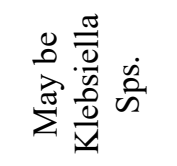 \\
\hline
\end{tabular}




\begin{tabular}{|c|c|c|c|c|c|c|c|c|c|c|c|c|}
\hline 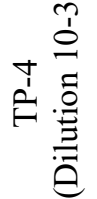 & 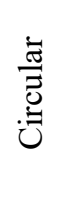 & 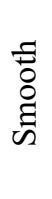 & 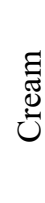 & $\stackrel{己}{0}^{\infty}$ & 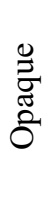 & - & + & - & - & - & - & 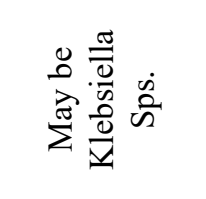 \\
\hline 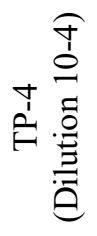 & 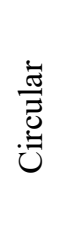 & 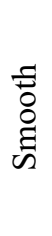 & 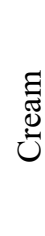 & 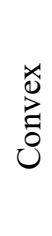 & 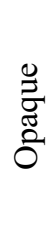 & - & + & + & - & - & - & 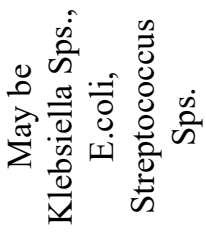 \\
\hline 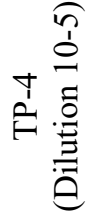 & 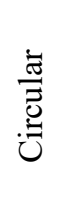 & 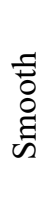 & 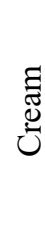 & $\sum_{0}^{0}$ & 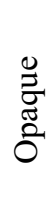 & - & + & + & - & - & - & 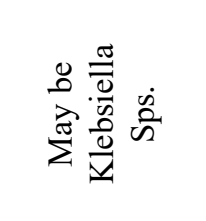 \\
\hline
\end{tabular}

* GW - Ground Water, TP - Tap Water

After Gram staining was performed the samples were then subjected to various biochemical test and were scrutinized and thereby finding the genus of the microbes present in TP2 sample the growth of fungus was established by plating the selected isolate in Potato Dextrose Agar along with Rifamycin $(30 \mathrm{mg} / \mathrm{l})$ to eliminate the bacterial growth in the media with the above biochemical characterization the microbes that are identified are E.Coli, Streptococcus Sps., Klebsiella Sps., Fugus.

The presence of E.coli is confirmed by MPN test, Streptococcus sps., was identified by its growth on specific media Blood agar.

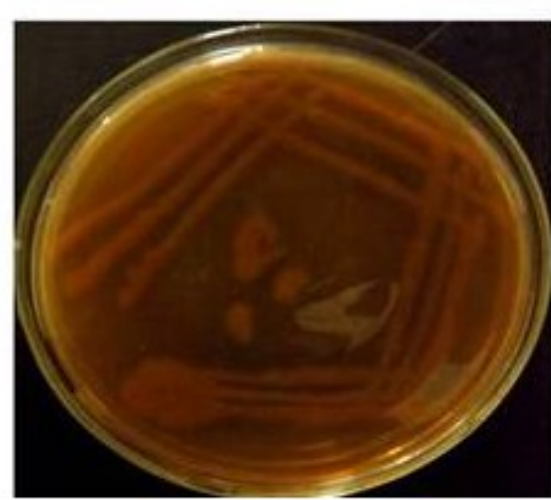

StreptococcusSps. grown on blood agar plate.

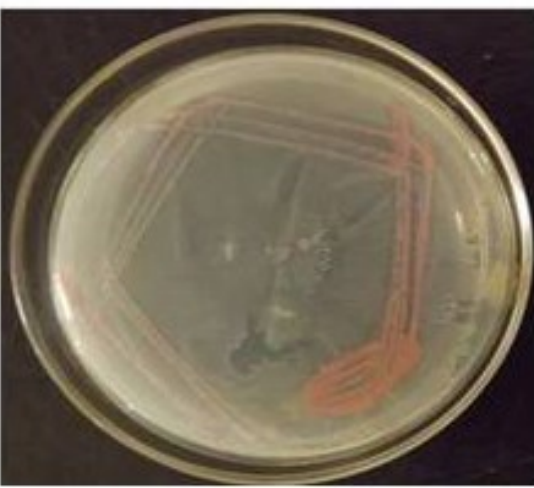

Fungus grown on Potato Dextrose Agar(PDA). 
Table 4. Physico - Chemical analysis of Water Samples.

\begin{tabular}{|c|c|c|c|c|c|c|}
\hline Sample & $\begin{array}{c}\text { Residual } \\
\text { Chlorine }\end{array}$ & $\begin{array}{c}\text { Dissolved } \\
\text { Oxygen }\end{array}$ & Nitrate & Ammonia & Sulphide & Sulphate \\
\hline $\mathrm{GW} 1$ & - & - & $0.03 \mathrm{mg} / \mathrm{L}$ & - & $1.6 \mathrm{mg} / \mathrm{l}$ & $20 \mathrm{mg} / \mathrm{L}$ \\
\hline $\mathrm{TP} 1$ & - & $4.9 \mathrm{mg} / \mathrm{L}$ & $0.04 \mathrm{mg} / \mathrm{L}$ & $0.3 \mathrm{mg} / \mathrm{L}$ & - & $0.2 \mathrm{mg} / \mathrm{L}$ \\
\hline $\mathrm{GW} 2$ & - & - & $0.06 \mathrm{mg} / \mathrm{L}$ & - & - & $11.6 \mathrm{mg} / \mathrm{L}$ \\
\hline TP2 & - & $5.6 \mathrm{mg} / \mathrm{L}$ & $0.03 \mathrm{mg} / \mathrm{L}$ & - & $1.6 \mathrm{mg} / \mathrm{l}$ & - \\
\hline TP3 & - & - & - & $0.5 \mathrm{mg} / \mathrm{L}$ & - & - \\
\hline GW3 & - & - & $1.7 \mathrm{mg} / \mathrm{L}$ & $0.2 \mathrm{mg} / \mathrm{L}$ & - & $13 \mathrm{mg} / \mathrm{L}$ \\
\hline TP4 & - & $4.6 \mathrm{mg} / \mathrm{L}$ & - & $0.2 \mathrm{mg} / \mathrm{L}$ & - & - \\
\hline
\end{tabular}

* GW - Ground Water, TP - Tap Water

After biochemical characterization and physicochemical analysis of water samples was done to identify an appropriate and apt dose of Permanganate to kill the microbes an also making the water available for human consumption the dosage was set within the permissible limit of B.I.S.

\section{CONCLUSION}

The bacterial colonies were reduced from 200 to 30 with a minimum dose of $\mathrm{KMnO}_{4}$ at $2 \mathrm{mg} / \mathrm{l}$. After treatment, the amount of manganese was found to be within the permissible limit. Awareness about water sanitation among masses is poor, dose based disinfection of water, depending on the bacterial count and species present, using a common and cheap chemical like $\mathrm{KMnO}_{4}$ can be demonstrated at local level without compromising with aesthetic value [1-4].
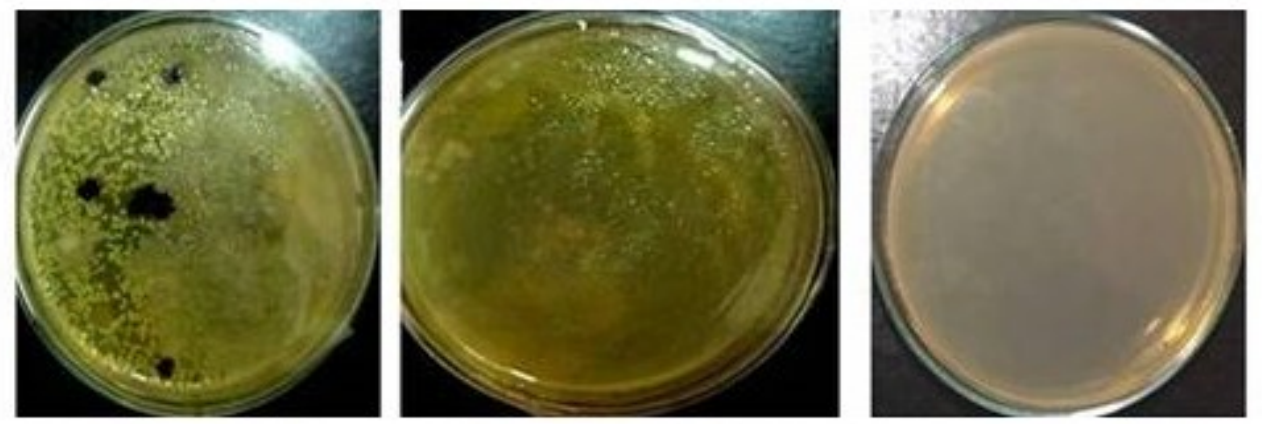

Before treatment

After treatmentat 1mg/ After treatmentat 2mg/dose dose 


\section{References}

[1] AWWA (American Water Works Association). Guidance Manual for Compliance with the Filtration and Disinfection Requirements for Public Water Systems Using Surface Water Sources, 1991.

[2] Banerjea R., Ind. Med. Gaz. 85 (1950) 214-219.

[3] Ficek K. J., J. E. Boll, Aque. 7 (1980) 153-156.

[4] George D. B., V. D. Adams, S. A. Huddleston, K. L. Roberts, M. B. Borup, Case Studies of Modified Disinfection Practices for Trihalomethane Control, Potassium Permanganate. AWWAR and AWWA, Denver, CO, 1990.

[5] Hazen and Sawyer. Disinfection Alternatives for Safe Drinking Water. Van Nostrand Reinhold, New York, NY, 1992.

[6] Holzgraefe M. et al., Journal of Toxicology and Clinical Toxicology 24 (1986) 235-244; erratum in Journal of Toxicology and Clinical Toxicology 24 (1986) 462.

[7] K. R. Aneja, Experiments in Microbiology \& Biotechnology New Age Publishers, 2003, p. 69.

[8] Bergey David. H., John G., Noel R. Krieg, Peter H. A. Sneath, Bergey's Manual of Determinative Bacteriology $9^{\text {th }}$ edition, Lipincott \& Wikins. ISBN 0-683-00603-7, 1994.

[9] Hans G. Schlegal, Christiane Zaborosch. General Microbiology $7^{\text {th }}$ edition, Thieme Verlag, Stuttagout New York, 1992, p. 310.

[10] Meynell G. G., E. Meynell, Theory and Practice in Experimental Bacteriology. New York: Cambribge University Press, 1965.

[11] Norris J. R., D. W. Ribbins, eds., Methods in Microbiology. New York and London: Academic Press, 1969.

[12] Gerhardt P., R. G. E. Murray, R. N. Cotilow, E. W. Nester, W. A. Wood, N. R. Krieg, G. B. Philips, Manual of Methods for General Bacteriology. Washington: American Society for Microbiology, 1981.

[13] Starr M. P., H. Stolp, H. G. Truper, A. Ballows, H. G. Schlegel, The Prokaryotes. New York, Heidelberg, and Berlin: Springer-Verlag, (1981).

[14] Gottschalk G., Bacterial Metabolism. New York, Heidelberg, and Berlin: SpringerVerlag, 1979.

[15] H. J., P. S. Linda, M. Shewood, Microbiology $5^{\text {th }}$ edition, McGraw Hill, 2008.

[16] Standard Methods for the Examination of Water and Waste water; APHA, AWWA and WEF, $21^{\text {st }}$, EDITION, 2005.

[17] Tassadaq Hussain, et al., African Journal of Microbiology Research 7(16) (2013) 1579-1590. 